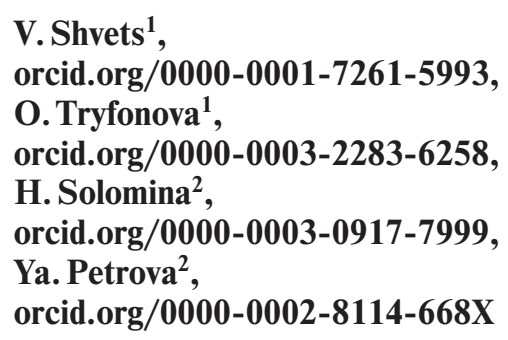

1 - Dnipro University of Technology, Dnipro, Ukraine, e-mail: elenatriphonova@gmail.com

2 - Dnipropetrovsk State University of Internal Affairs, Dnipro, Ukraine

\title{
THEORETICAL AND METHODOLOGICAL FOUNDATIONS FOR THE EVALUATION OF MANAGEMENT EFFICIENCY OF JOINT INVESTMENT INSTITUTIONS
}

Purpose. The study is aimed at substantiation of theoretical and methodological foundations for the integrated evaluation of management efficiency of joint investment institutions from the viewpoint of formation of their asset portfolios and potential of the schemes on the whole.

Methodology. Basic results of the study were obtained with the use of scientific and theoretical analysis of academic papers as well as information and analytical data concerning the problematics of activities by the joint investment institutions. A technique of scientific generalization was applied to state the science-based problems, and to formulate conclusions according to the study results. The proposed theoretical and methodological approach to evaluate management efficiency of the joint investment institutions has been substantiated with the use of analytical and system methods.

Findings. The economic prerequisites, influencing heavily management efficiency of the joint investment institutions, their investment attractiveness, and economic security, have been determined. A role of consideration of cost value of the joint investment institutions in the process of their management efficiency evaluation is emphasized. An integrated approach to evaluate management efficiency is proposed which, on the one hand, provides evaluation of the efficiency of formation of investment portfolio of the scheme involving earning yield as well as riskiness of the asset portfolio together with the time-dependent stability measure of income receipts on the investment assets; on the other hand, it forecasts efficiency of the scheme on the whole. Tendencies for substantiation of managerial decisions aimed at the improved efficiency of the joint investment institutions are outlined.

Originality. Methodological foundations to evaluate management efficiency of a collective investment scheme have been substantiated theoretically. They involve the integrated evaluation of its investment portfolio yield taking into consideration dynamic characteristics of asset value, the portfolio riskiness, and efficiency of the scheme on the whole.

Practical value. The proposed theoretical and methodological approach to evaluate management efficiency of a collective investment scheme makes it possible to improve rapidness of managerial decision-making as for the yield enhancement and risk mitigation of the scheme asset portfolio; it can favour the provision of all players of the collective investment market with the objective information on investment attractiveness and on the degree of financial security of the investment fund and asset management companies.

Keywords: joint investment institutions, management efficiency, evaluation of profitability, investment asset portfolio

Introduction. Collective investment market is the environment where conditions for financial provision of economy progress are created by means of investment process and through the cash flow acceleration. Joint investment institutions (JIIs) are the important sources of investment capital playing an important role in its redistribution and stimulating investment process within any country at the expense of domestic and foreign placement of funds. Assets of all current Ukrainian JIIs are managed by asset management companies (AMCs) being legal entities and pursuing professional activities only according to legal regulations, and the obtained license.

Currently, the investment market is imperfect institutionally being characterized by structural distortions. Among other things, they result from nontransparency of regulations; propensity of players to violations due to legislative inconsistency; and due to availability of institutional development barriers.

It is expedient to involve principles of institutional approaches in the process of study on activities by joint investment institutions since relevant environment stipulates selection of the appropriate managerial tools. Under such conditions, activation of processes intended to evaluate management efficiency of JIIs becomes an important aspect of institutional orientation in terms of their asset management as well as in terms of their total efficiency having no consistent method-

(c) Shvets V., Tryfonova O., Solomina H., Petrova Ya., 2020 ological foundations; first of all, it concerns information diffusion. Moreover, results of such evaluation would also help understand the degree of investment attractiveness of JIIs as well as their economic security depending heavily upon a degree of operational imbalance from the viewpoint of riskiness-profitability ratio.

Solving the problems needs substantiation of methodological foundations to evaluate management efficiency of JIIs in Ukraine in the context of return of assets, investment attractiveness as well as financial security of the schemes.

Literature review. A number of papers by national and foreign theoretical scientists and practitioners concern the problem of hypothetical and applied foundations intended to provide efficiency by JIIs, management of their assets, and concretization of theoretical and methodological approaches on their basis. Specifically, studies by N. S. Pedchenko, M. O. Duda [1], and A. O. Shevchenko [2] are oriented on the concept of efficient financial provision of JIIs; they also identify specific features and components of financial assets of the JIIs as well as formulate recommendations concerning priority of tasks of financial support for the activities of such schemes. A problem of speculative operations in the security market, being the key source of financial risk, has become a subject of research for L. S. Seliverstova [3]. However, both national and foreign scholars focus traditionally on the solution of a problem of the investment portfolio formation and management: S. Greiner and S. Stoianov [4] propose a portfolio rating me- 
thodology from the viewpoint of investment attractiveness. The methodology is based upon the consideration of the expected reward required for an investor to take risks in the context of a structure of asset pricing; V. A. Cherevatenko [5] and V.P. Mazurenko [6] place the emphasis on the diversification of an investment portfolio assets to provide its equilibrium involving uncertainty in terms of each yield source and advantages of the investors; in the context of a system approach as for the formation of optimal portfolio of financial investment, V. L. Masliuk [7], O. V. Mykhailenko, and V. O. Remeniuk [8] determine stages of the process of analysis of investment risk of securities while proposing methodological approaches to carry out the analysis; G. G. Gaidai [9] considers securitization opportunity as well as the use of financial engineering to minimize the investment risks; E. Elton and others [10] propose optimization and diversification of the investment asset portfolio relying upon measurement of yield correlation of a certain security, and market index.

Unsolved aspects of the problem. Generalization of the results means that a process of making the efficiency of JII management equal to the efficiency of their asset management takes place; moreover, a number of such important aspects as cost management of the scheme, staff efficiency and others are ignored. Nevertheless, while paying tribute to the research results by the abovementioned scholars, it should be noted that their approaches differ even in terms of structure and composition as for the efficiency evaluation of asset management having influence on the set of the estimated figures as well as on the approach to the evaluating procedure itself and on the further interpretation of its results.

Purpose. As for the necessity for investment process participants to obtain objective information concerning investment attractiveness, financial security, and sustainable activities by JIIs stipulates the need to develop theoretical and methodological foundations for the integrated evaluation of the JII management from the viewpoint of formation of their asset portfolios and operating efficiency of the schemes on the whole.

Results. The basic concepts of market efficiency, grounded in the linear nature of environmental processes, market statics, and mathematical tools, relying upon the normal distribution indices, dispersion, and linear models, are unacceptable in terms of the changing environment.

The paradigm of a collective investment market is based upon the stable information asymmetry, capable of causing crisis phenomena and working upon evaluating technique and management of financial tools. The necessity to make decisions in the context of huge data array and during short periods of time results in the asset value deformation being an objective phenomenon as well as the reason of market uncertainty anticipating the occurrence of imbalances.
In the context of the law of Ukraine "On joint investment institutions" [11], both legislative and organizational backgrounds for endowment foundations have been determined for efficient attraction and efficient allocation of the investment financial resources as well as for operations by joint investment entities, and termination of their activities; moreover, definite requirements for their asset management have been specified, namely concerning the composition, structure, and maintenance of such assets, issuance, circulation, accounting, and buyout. In addition, the procedure for disclosure of information concerning JII activity has been provided.

Assets of the joint investment institutions involve property of the investment funds formed at the expense of finance attracted from investors and income from the asset operations. Along with that, JII liabilities include long-term equities, the current payments to participants and shareholders, and transaction costs. The abovementioned components are basic ones since values affect the final financial result of JII activities, i.e. net asset total.

As it is understood from the analysis of performance indicators (Fig. 1), during the last eleven years the number of the established JIIs (i.e. licensed) continues its increase. The process takes place irrespective of minor decrease during 2014 2016 stipulated by complication of socioeconomic as well as economic situations in the country. Moreover, asset value of such JIIs experienced shorter attrition period (the year of 2016 only). The period did not impact general nature of the dynamics. Furthermore, that helps the institutions augment their capital (average asset value per one JII increased from UAH 83.8 million in 2009 up to UAH 355.8 million in 2019).

The two indices considered have made it possible to form a tendency to increase described by polynomial tendencies being adequate to real conditions (i.e. F-tests being 28.2 and 363.0 respectively and exceeding critical values by 4.35 and 4.46 respectively). In the context of the polynomial tendencies, average increment value rates of JIIs are $26.2 \%$ exceeding increment rates of their number being $13.6 \%$.

Relying upon the developed tendencies, it is possible to forecast, with a high degree of approximation accuracy (since determination coefficients are more than 0.5 ), the increase in JII number up to 1.5 thousand institutions. Their asset value will increase up to UAH 357 million. Hence, the tendencies support not rapid but stable consolidation of a joint investment market.

According to the current legislation [13], net asset value is calculated as the difference between sizes of the assets and the investment fund liabilities in terms of present-day prices at the evaluation moment. In turn, it influences directly the JII profitability characterizing the net asset value per a security as of the period beginning and taking into account the fund expenses (i. e. rewards for services by the asset management company,

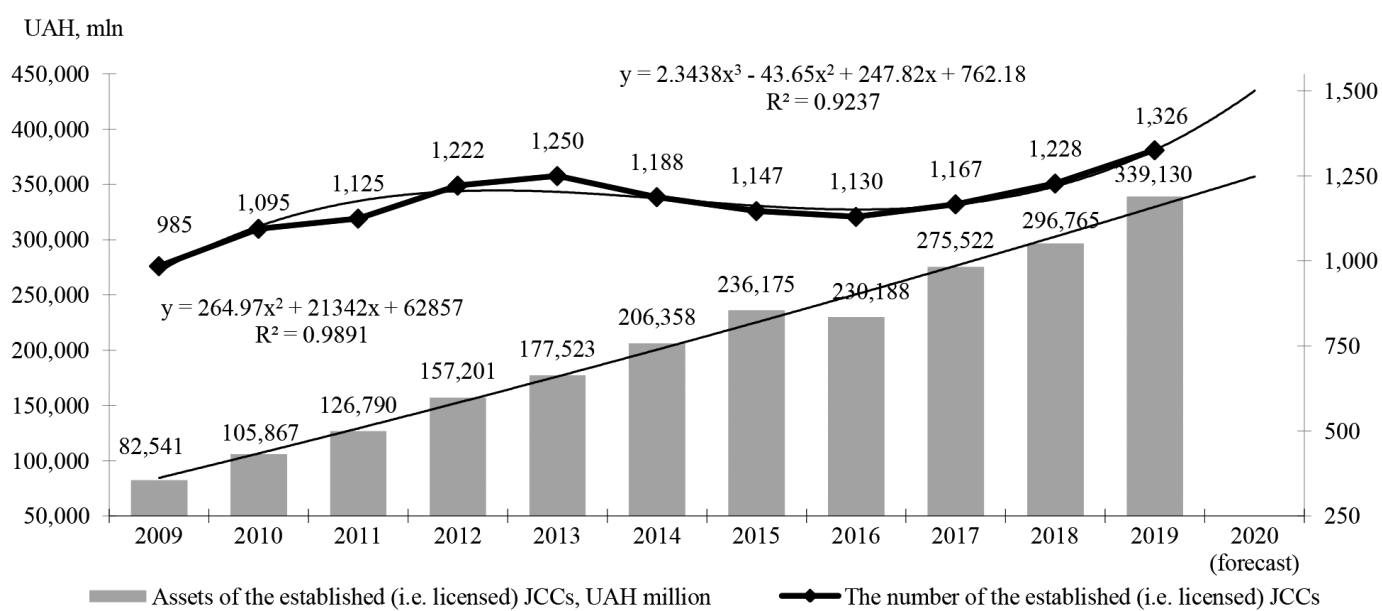

Fig. 1. Dynamics and forecast of the established number of JIIs and value of their assets [12] 
the depositary, the appraiser, and the auditor listed in the issue prospectus of the joint investment institution).

Fig. 2 explains that net assets value of Ukrainian JIIs (exclusive of venture ones) experienced significant fluctuations during the last two years. Thus, after the a three-quarter stability period early in 2018, its end demonstrated rapid growth of net asset value from UAH 8219.6 million up to UAH 15395.0 million, i.e. by 1.9 times. That was stipulated by winding-up of numerous AMCs due to the set of macroeconomic factors (i.e. temporary break in cooperation with the IMF and four times rate increase caused by the NBU expected inflation rates and financial stability risks) as well as distribution of their assets among companies stayed in the joint investment market and those ones which managed to provide substantial growth in the net asset value after the situation stabilization since they could rebuild their investment portfolios in the context of moderate increase in stock indices.

The trend to the net asset value growth, formed mainly owing to the mentioned jump in the net asset value, leaves polynomial tendency of a high-degree approximation accuracy starting from the $2^{\text {nd }}$ quarter of 2019 (since determination coefficient is more than 0.5 ; F-test is 5.87 exceeding critical 5.79 value) became of a reverse nature supporting high likelihood of further efficiency loss in JII activities.

However, calculation of the abovementioned indices is not sufficient to identify tendencies to improve investment portfolio management as well as the JII activities on the whole. Moreover, lack of involvement of time-dependent stability of asset profitability of the investment portfolio cannot provide adequate objectivity in the process of evaluation of investment attractiveness of the JII as well its economic security degree.

Free assets in the form of financial flows, and equity rights are the joint investment object. They are represented by just titles as well as claims involving constant governmental control through a system of relevant bodies. A procedure of JII establishment is based upon meeting legal requirements as for their organizational structure and mechanism of regulation of its activities on the part of the main regulator, and government agencies.

Efficient establishment and operational behaviour of joint investment institutions are represented by a body of methodological approaches to the formation of the investment fund capital, determination of structural parameters of assets, and the asset portfolio management as well as evaluation of its efficiency.

JII assets are represented by the fund properties formed at the expense of investor finance, and operations with it. The National Securities and Stock Market Commission (NSSMC) regulates a list of financial tools of asset investment portfolio.

It is common knowledge that diversification is the determinative factor of investment portfolio formation while select-

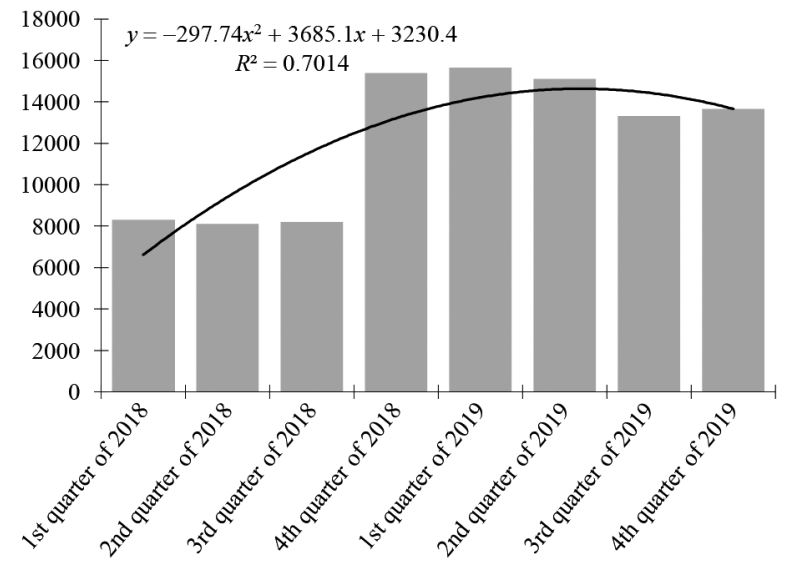

Fig. 2. Dynamics of net asset value of JIIs (exclusive of venture ones), UAH million [12] ing investment in the least risky and the most profitable tools able to provide implementation of the investment strategy of JII with corresponding allowance for the fund group and profit taxation in terms of certain tools. Accordingly, the current risk minimization and profitability maximization as well as long-term ones, resulting in the determined liquidity level, are the key tasks of the effective formation of investment portfolio and its management.

Formalization of composition and structure of portfolio of joint investment institution follows the available theoretical and methodological approaches inclusive of investment strategy selected by the authorities; it is determination of ratio between indices of market value of the financial assets and intrinsic ones.

It should be noted separately that fictitious (i.e. technical) securities may circulate at the joint investment market. They are listed in terms of time-independent nominal value (i. e. intrinsic one) since tangible assets do not back them; moreover, they have been formed from the viewpoint of book value of the capital. It is not expedient to involve such securities in investment portfolio since they will not back future asset growth; their exclusion from the portfolio will favour the improved informational objectivity concerning investment attractiveness of the JII from the viewpoint of the potential investors. Hence, securities should be selected depending upon their fair value rather than upon their intrinsic value which will help determine reserve of their overvaluation or undervaluation. In future, that will favour, firstly, the reduced risk likelihood connected with low asset prices (since there is a reserve for decrease during the market decline). Secondly, that favours getting super profits from the selected financial assets in the process of market growth.

The well-timed disclosure of the reliable information to security issuers is the fundamental principle of the regulated market of joint investment helping evaluate the asset fairly and acting as the prerequisite for making the substantiated decisions concerning the asset integration in JII investment portfolio.

Fair asset value is a comparison between inside price and market price. The former is equal to capital stock of an issuer thus helping determine overvaluation or undervaluation value of the asset in market. Since a process of internal price determination, based upon stock exchange quotation as well as upon curb trading, may involve manipulations (i.e. conclusion of numerous agreements, minor in size, in terms of prices being acceptable for market players) then it is expedient to determine internal value of assets, circulating within a secondary market, relying upon the value amounting to the capital stock of the issuer. The approach will help cut the likelihood of price manipulation while making a process of asset value calculation to be transparent.

In the context of JIIs, determination of fair value for financial asset is connected with heavy transaction expenditures conditioned by the necessity to search for information concerning an issuer of securities, forming the investment portfolio, and to analyse the data. Moreover, V.Zakamulin [14] mentions that the current strategies, intended to manage risks of investment portfolio, involve permanent review of its composition, which also affects the total of the transaction costs. Such expenditures influence heavily the final results of activities by the institutions; moreover, they should be reduced by means of implementation of modern analytical methods and information technology. In this context, as it is mentioned in [15], NSSMC implementation of a new e-system of the integrated disclosure of information concerning emission prospectuses, annual reports, and quarterly reports as for operating results of issuers will favour simplification of the reporting process as well as its transparency provision, and, hence, reduction of transaction costs.

High volatility of joint investment market needs adjustment of criterion basis of JII ranking, carried out by Ukrainian Association of Investment Business (UAIB) according to pro- 
cedure [16], and should provide the investment process participants with operative and reliable information concerning investment attractiveness as well as a degree of financial security of JIIs. In this connection, the indices, characterizing investment portfolio reliability, a risk degree per income unit as well as efficiency indices of management of the institutions on the whole become rather topical.

Hence, evaluation of JII efficiency together with the investment portfolio evaluation is the basis to determine management efficiency of the institution on the principles of the integrated analysis of asset profitability growth involving their dynamic characteristics and to reduce the investment risks. In this context, special attention should be paid to the analysis of stability of activities by the institutions during certain periods; to the reconciling of interests of JII participants with objectives of a managing company set from the viewpoint of the investment fund class; and to the introduction of permanent accounting of the JII asset liquidity level.

Hence, implementation of the integrated methodological approach, intended to evaluate JII management efficiency, involves a number of stages: identification of the basic characteristics of the securities forming investment portfolio; calculation of the profitability indices as well as riskiness of the investment portfolio; determination of the overestimation/underestimation degree of the investment assets from the viewpoint of stability of income generation; calculation of index of the JII efficiency; analysis of the calculation results as for the success of the investment portfolio and JII activities; and substantiation of the managerial decisions aimed at their improvement.

Investment portfolio profitability is determined according to [16] in terms of the net asset value changes per one security. As for the evaluation of the investment portfolio riskiness, the following indices of the available ones have become the most popular in Ukraine: volatility degree $N A V$ (net asset value) per one security, and Sharpe ratio, the use of which has been involved by a methodology for open JII ranking [16]. Ranking of other classes in terms of the indices is possible if only daily reports are submitted to AMC concerning net asset value of corresponding funds per one security. Moreover, the use of Sharpe ratio (characterizing investor premium per a risk unit in the form of extra income to compare with riskless asset investment, and being applied as JII management efficiency index) while evaluating portfolio (funds), whose expected profitability cannot correspond to a normal distribution, is limited due to high excess degree or negative skewness being typical for many financial assets and portfolios. Furthermore, the comparison of funds on the basis of such evaluation makes sense if the values of the coefficient, demonstrating risk premium availability (i.e. extra income over riskless rate), are positive values. If risk premium is not available (i. e. either zero value, or negative value of difference between average daily profitability ratio, and average daily NBU rate over a period) it means that all the funds were managed ineffectively during certain period since profitability of the riskless asset (i. e. NBU rate) was higher than profitability of the funds in terms of the time interval. Contrary to the world practices, using a benchmark, it is expedient for the national joint investment institutions to use the NBU rate as a riskless asset.

The abovementioned problems of use of JII ranking parameters have resulted in the fact that actually the UAIB determines rank of the funds only in terms of $N A V$. Consequently, it prevents from the possibility to evaluate the efficiency of management of the funds as well as their investment attractiveness, and obtain the objective information concerning the certain JII rank in terms of specific indices.

The index of timing stability of the investment profitability characterizes intensity of changes in the market stability of JII assets for a certain period while providing indirect evaluation of riskiness level and investment liquidity with consideration of transaction expenses. The index is calculated as a ratio between absolute changes in the market value of the net assets in terms of a certain period beginning and end, and the asset value difference per the period, i. e.

$$
T_{S}=\frac{\left(N A V_{p . e}-N A V_{p . b}\right) \cdot t}{\sum_{3=1}^{n}\left(V A_{p . e i}-V A_{p . b i}\right) \cdot 12},
$$

where $N A V_{p . e}, N A V_{p . b}$ are net asset values of the investment fund per the period end and beginning respectively; $V A_{p . e}$, $V A_{p . b i}$ is the value of the $i^{\text {th }}$ asset (i.e. security) per the period end and beginning respectively, $i=1, n ; t$ is an evaluation period, months, $t=1.12$.

The index of timing stability of the investment profitability is calculated separately for the periods with positive difference in net assets of investment fund and with negative difference. Its values are 0 to 1 if figures of a fiscal period demonstrate positive difference between investment in assets and its value in terms of the period end. If the difference is negative, then $T_{s}$ may be -1 to 1 . In this context, the larger the amplitude of asset value changes is during the analysed period under minor $N A V$ changes, the closer to zero the values are specifying inefficiency of investment strategy of the AMC and low level of financial security of the JII.

Together with the efficiency and riskiness indices of the investment portfolio as well as timing stability of the investment profitability, JII management efficiency foresees involvement of changes in the net asset value as the total index of the JII management efficiency evaluation, i.e.

$$
K_{N A V}=\frac{N A V_{p . e}}{N A V_{p . b}} .
$$

The final stage of management efficiency of joint investment institutions involves analysis of calculation results of the abovementioned indices and substantiation of managerial decisions concerning the institution activities whose essence depends upon the fund class.

According to the proposed methodological approach, management efficiency of three classes of funds has been evaluated (i.e. asset funds, bond funds, and multi-asset class funds) (Table).

Management of JIIs, whose assets are represented by shares, may be considered as most efficient, since they have demonstrated the highest stability of profitable activities in the context of average profitability level as well as average risk of their investment asset portfolios. At the same time, the JIIs, whose funds are represented by bonds, are characterized by a high level of the investment risk due to degradation of situation in the security market. However, the funds have rather high asset profitability. Attention is drawn to the fact that this year the total financial results of activities of such JIIs have experienced maximum degradation, stipulated by significant operational costs, notwithstanding high portfolio profitability.

The obtained results help conclude that in terms of longterm perspective, the asset funds, providing maximum profits and rather stable profits, are the most attractive for potential investors. In this context, management of such a JII should align active strategy of the investment asset portfolio management which involves constant control and revision of its composition in terms of mandatory monitoring of the expenditures connected with management of the fund property (administrative expenses as well as operational ones are meant).

If short-term investment is implied, then multi-asset fund class is the most attractive from the viewpoint of profitability volatility ratio to compare with bond funds being financial risky as for the investment.

Conclusions. Determination of economic prerequisites of efficient management of joint investment institutions, their investment attractiveness, and economic security made it possible to substantiate the integrated approach to evaluate management efficiency of JII from the viewpoint of the efficient formation of investment portfolio and activities by the institu- 
JII management efficiency indices

\begin{tabular}{|c|c|c|c|c|}
\hline JII management company & $\begin{array}{c}\text { Profitability } \\
\text { of investment asset } \\
\text { portfolio }\end{array}$ & $\begin{array}{c}\text { Volatility } \\
\text { of investment asset } \\
\text { portfolio }\end{array}$ & $\begin{array}{l}\text { Timing stability } \\
\text { of investment } \\
\text { profitability }\end{array}$ & $\begin{array}{l}\text { Changes in JII net } \\
\text { asset value }\end{array}$ \\
\hline KUA PLATINUM CAPITAL ltd (asset fund) & 4.09 & 1.14 & 0.301 & 0.84 \\
\hline KUA ARGENTUM TOB KУA ltd (asset fund) & 4.07 & 2.44 & 0.117 & 0.75 \\
\hline$K U A U F N$ ltd (multi-asset class fund) & 3.39 & 1.66 & 0.214 & 0.64 \\
\hline KUA OPTIMUM ltd (multi-asset class funds) & 2.16 & 0.98 & 0.306 & 0.57 \\
\hline KUA OTP Klasychny ltd (multi-asset class funds) & 1.97 & 0.89 & 0.276 & 0.24 \\
\hline KUA OTP Valiutny ltd (bond fund) & 2.92 & 5.49 & 0.301 & 0.37 \\
\hline $\begin{array}{l}\text { KUA UNIVER. UA/Taras Shevchenko: Fond Zaoshchadzhen } \\
\text { ltd (bond fund) }\end{array}$ & 4.69 & 6.67 & 0.316 & 0.41 \\
\hline
\end{tabular}

tion on the whole. Evaluation of the efficiency of investment portfolio of assets relies upon the use of indices of profitability and riskiness of the asset portfolio together with the index of timing stability as for making gains from the investment assets.

It has been defined that the value of transaction expenses by the joint investment institutions, connected with search and analysis of information concerning issuers of securities, forming the investment portfolio, influences heavily the efficiency of the institutions. To take into consideration a value of transaction expenses, JII efficiency is proposed to be evaluated in terms of changes in net asset value.

The tendencies to substantiate managerial decisions as for the improvement of their activity have been outlined from the viewpoint of strategies to form investment asset portfolio and to formulate operations of the institutions on the whole.

Implementation of the proposed approach will make it possible to save time for managerial decision making by AMCs concerning investment portfolio management as well as the JII activities on the whole. Moreover, it will favour attraction of potential investors owing to their provision by the tools of objective evaluation of the investment potential and economic security of JIIs.

First of all, prospects of future studies in the field of management of joint investment institutions depend upon the formation of the integrated index to evaluate management efficiency and identification of nonmarket factors effecting financial results of the activities by the institutions.

\section{References.}

1. Pedchenko, N. S., \& Duda, M. O. (2015). Functional Model of Financial Securing the Activities of Institutions of Joint Investment. Business Inform, 9, 346-352.

2. Shevchenko, A. O. (2017). Institutes of joint investment in the Ukrainian stock market. AIC Economics and Management, 1, 28-35.

3. Seliverstova, L. S. (2016). Creating the optimal portfolio of financial investments corporation. Scientific Bulletin of Polissia, 2(6), 127-131.

4. Greiner, S. P., \& Stoyanov, S. V. (2019). Portfolio Scoring by Expected Risk Premium. The Journal of Portfolio Management, 45(4), 83-90. https://doi.org/10.3905/jpm.2019.45.4.083.

5. Cherevatenko, V.A. (2014). Determination of the structure of assets for investment fund with a conservative strategy. Foreign Trade: Economics, Finance, Law, 2(73), 87-92.

6. Mazurenko, V. P., \& Tikhonravova, E. O. (2014). Concept of investment portfolio formation and management within globalization process. Scientific Bulletin of Kherson State University. Series "Economic Sciences", 9(3), 25-29.

7. Masliuk, V. L. (2016). Organization and methods of risk analysis activities of collective investment institutions: the problematic issues and ways of solving. Problems of Theory and Methodology of Accounting, Control and Analysis, 2-3(35), 253-259.
8. Mykhailenko, O. V., \& Remeniuk, V.O. (2018). Formation and management of a portfolio of financial investments. State and regions. Series: Economics and Business, 2(101), 91-96.

9. Gaidai, G. G. (2019). Investment portfolio of the enterprise as an important component of investment strategy. Herald of National Transport University, Series "Economics", 2(44), 4855. https://doi.org/10.33744/2308-6645-2019-2-44-048-055. 10. Elton, E.J., Gruber, M.J., Brown, S.J., \& Goetzmann, W. N. (2014). Modern Portfolio Theory and Investment Analysis. John Wiley \& Sons, Inc.

11. Verkhovna Rada of Ukraine. Legislation of Ukraine (n.d.). On Joint Investment Institutions. The Law of Ukraine No. 2299III (2014, January 1). Retrieved from http://zakon3.rada.gov. ua/laws/show/5080-17.

12. Ukrainian Association of Investment Business (n.d.). Quarterly and annual survey of asset management market. UAIB. Retrieved from http://www.uaib.com.ua/analituaib/publ_ici quart.html.

13. Verkhovna Rada of Ukraine. Legislation of Ukraine (n.d.). On approval of the Regulation on the procedure for determining the value of net assets of joint investment institutions: Decision of State Securities and Stock Market Commission No. 1336 (2013, July 7). Retrieved from https://zakon.rada.gov. ua/laws/show/z1444-13.

14. Zakamulin, V. (2019). Volatility Weighting over Time in the Presence of Transaction Costs. The Journal of Wealth Management, 21(4), 33-45. https://doi.org/10.3905/jwm.2019.21.4.033. 15. Kosova, T. D., \& Yaroshevska, O. V. (2019). Concepts of financial regulation of stock activity of economic entities (2019). In: T. D. Kosova, \& N. O. Slobodianiuk (Eds.). Theoretical and methodological bases of Ukraine's financial system development through innovation and investment strategies: collective monograph, (pp. 33-43). Kryvyi Rih: DonNUET.

16. Ukrainian Association of Investment Business (2020). Methods of Ranking of Asset Management Companies and Joint Investment Institutions (Unit and Corporate Investment Funds) by Results of Their Activity. Retrieved from https://www.uaib. com.ua/about-uaib/internal-docs/methodologies/16041.

\section{Теоретико-методичні засади оцінювання ефективності управління інститутами спільного інвестування}

\section{В. Я. Швець ${ }^{1}$, О. В. Трифонова ${ }^{1}$, Г. В. Соломіна ${ }^{2}$, Я. I. Петрова ${ }^{2}$}

1 - Національний технічний університет «Дніпровська політехніка», м. Дніпро, Україна, e-mail: elenatriphonova@ gmail.com

2 - Дніпропетровський державний університет внутрішніх справ, м. Дніпро, Україна 
Мета. Дослідження спрямовано на обгрунтування теоретико-методичних засад комплексного оцінювання ефективності управління інститутами спільного інвестування з позиції формування їхніх портфелів активів та ефективності діяльності інститутів у цілому.

Методика. Основні результати дослідження були отримані із застосуванням науково-теоретичного аналізу наукових публікацій та інформаційно-аналітичних даних із проблематики діяльність інститутів спільного інвестування. Постановка наукових завдань і формулювання висновків за результатами дослідження проводилися методом наукового узагальнення. Запропонований теоретико-методичний підхід до оцінювання ефективності управління інститутами спільного інвестування обгрунтований із застосуванням аналітичного й системного методів.

Результати. Визначені економічні передумови, що суттєво впливають на ефективність управління інститутами спільного інвестування, їхню інвестиційну привабливість та економічну безпеку. Підкреслена роль урахування величини витрат інститутів спільного інвестування при оцінюванні ефективності управління ними. Запропоновано комплексний підхід до оцінювання ефективності управління, що передбачає отримання оцінки, з одного боку, ефективності формування інвестиційного портфеля фонду з використання показників дохідності й ризикованості портфеля активів спільно з показником часової стабільності отримання доходу від інвестиційних активів, з іншого, - ефективності діяльності інституту у цілому. Окреслені напрями обгрунтування управлінських рішень щодо підвищення ефективності діяльності інститутів спільного інвестування.

Наукова новизна. Проведено теоретичне обгрунтування методичних засад оцінювання ефективності управління інститутом спільного інвестування, що передбачають комплексне оцінювання дохідності його портфелю інвестицій, зокрема з урахуванням динамічних характеристик вартості активів, та ризикованості портфеля, а також ефективності діяльності інституту у цілому.

Практична значимість. Запропонований теоретикометодичний підхід до оцінювання ефективності управління інститутом спільного інвестування дозволяє підвищити оперативність прийняття управлінських рішень щодо збільшення дохідності та зменшення ризикованості портфелю активів інституту, сприятиме забезпеченню учасників ринку спільного інвестування об'єктивною інформацією щодо інвестиційної привабливості та ступеня фінансової безпеки фондів і компаній з управління активами.

Ключові слова: інститути спільного інвестування, ефективність управління, оцінювання дохідності, інвестиційний портфель активів

\section{Теоретико-методические основы оценивания эффективности управления институтами совместного инвестирования}

\author{
В. Я. Швеи ${ }^{1}$, Е. В. Трифонова ${ }^{1}$, А. В. Соломина ${ }^{2}$, \\ Я.И. Петрова ${ }^{2}$
}

1 - Национальный технический университет «Днепровская политехника», г. Днепр, Украина, e-mail: elenatriphonova@gmail.com

2 - Днепропетровский государственный университет внутренних дел, г. Днепр, Украина

Цель. Исследование направлено на обоснование теоретико-методических основ комплексной оценки эффективности управления институтами совместного инвестирования с позиции формирования их портфелей активов и эффективности деятельности институтов в целом.

Методика. Основные результаты исследования были получены с применением научно-теоретического анализа научных публикаций и информационно-аналитических данных по проблематике деятельность институтов совместного инвестирования. Постановка научных задач и формулирование выводов по результатам исследования проводились методом научного обобщения. Предложенный теоретико-методический подход к оценке эффективности управления институтами совместного инвестирования обоснован с применением аналитического и системного методов.

Результаты. Определены экономические предпосылки, существенно влияющие на эффективность управления институтами совместного инвестирования, их инвестиционную привлекательность и экономическую безопасность. Подчеркнута роль учета величины затрат институтов совместного инвестирования при оценке эффективности управления ними. Предложен комплексный подход к оценке эффективности управления, предусматривающий получение оценки, с одной стороны, эффективности формирования инвестиционного портфеля фонда с использованием показателей доходности и рискованности портфеля активов совместно с показателем временной стабильности получения дохода от инвестиционных активов, с другой, - эффективности деятельности института в целом. Обозначены направления обоснования управленческих решений по повышению эффективности деятельности институтов совместного инвестирования.

Научная новизна. Проведено теоретическое обоснование методических основ оценивания эффективности управления институтом совместного инвестирования, которые предусматривают комплексную оценку доходности его портфеля инвестиций, в том числе с учетом динамических характеристик стоимости активов и рискованности портфеля, а также эффективности деятельности института в целом.

Практическая значимость. Предложенный теоретикометодический подход к оценке эффективности управления институтом совместного инвестирования позволяет повысить оперативность принятия управленческих решений по повышению доходности и уменьшению рискованности портфеля активов института, может способствовать обеспечению участников рынка совместного инвестирования объективной информацией об инвестиционной привлекательности и степени финансовой безопасности фондов и компаний по управлению активами.

Ключевые слова: институты совместного инвестирования, эффективность управления, оценивание доходности, инвестиционный портфель активов

Recommended for publication by O. V. Honcharenko, Doctor of Economic Sciences. The manuscript was submitted 29.01.20. 